\title{
From Surplus to Deficit Fiscal Policy
}

\author{
M. P. Afanas'ev ${ }^{a, *}$ and N. N. Shash ${ }^{b}$ \\ ${ }^{a}$ Institute of Economic Forecasting, Russian Academy of Sciences, Moscow, Russia \\ ${ }^{b}$ Plekhanov Russian University of Economics, Moscow, Russia \\ *e-mail: mstafan@gmail.com
}

Received March 15, 2020; revised March 19, 2021; accepted April 6, 2021

\begin{abstract}
The article discusses the reasoning associated with the change in the trajectory of the Russian budgetary policy in the current cycle and the substantiation of the forecast values of the main macroeconomic indicators used in the formation of the federal budget. The characteristics and analysis of the dynamics of the volumes of income and expenses are presented. The main theoretical concepts aimed at finding the optimal amount of debt financing for economic growth and the size of public debt are considered. The assessment of measures to balance the Russian budget in the context of the growth of public debt in the context of a decrease in budget revenues. The consequences of an increase in debt financing of the national economy are revealed and the values of indicators of Russia's debt sustainability are calculated.
\end{abstract}

Keywords: budget policy, budget surplus and deficit, macrofinancial stability, macroeconomic indicators, budget cycle, budget revenues and expenditures, public debt, debt financing of the economy

DOI: $10.1134 / \mathrm{S} 1075700721050026$

The crisis provoked by the "sanitary" war, which demanded state structures in different countries of the world carry out an unprecedented complex of mobilization measures, caused an obvious increase in inequality in budget revenues. This is not about social, but about macrofinancial inequality, i.e., the focus is not on households, but on the formation of the budgets of central governments, which were forced to radically change not only the structure of budget expenditures, but also the traditional methods of budgetary management.

In the context of the global economic downturn, provoked by anticrisis measures and measures of anticrisis policy, in Russia against the background of an unprecedented decline in economic activity, in particular, the following important economic changes requiring a deeper analysis have occurred:

-The transition from a surplus to a deficit budgetary policy (none of the numerous conclusions on the draft federal budget for 2021 and the planning period 2022-2023 found a place for this fundamental transition).

-The manifestation of a certain inconsistency between some aspects of general economic theory and budgetary practice that was applied in the 2021 budget (both in the draft budget itself and in other "budget documents").
-The unprecedented growth of the state debt of Russia and the expansion of debt financing of the economy.

Deficit vs. surplus in the context of the main macroeconomic indicators of the Russian federal budget. Discussing the first thesis, it is advisable to consider two circumstances: the lack of argumentation for a return to a deficit budgetary policy; the validity of the main macroeconomic indicators used in the preparation of the federal budget of Russia.

The results of the analysis of world budgetary practice have shown that in most countries (for example, Great Britain, Japan, United States) the fixed budget surplus was observed in the short term, not exceeding 2-3 years [1]. As for the choice of the vector of Russian budgetary policy, apart from stating the fact of the planned surplus during the past (2020-2022) and abandoning it in the current budget cycle, there were no reasonable comments and substantiated arguments.

It is logical that the global COVID-19 pandemic, continuing in the current (2021) year, has become a decisive factor in refusing to maintain a surplus regime. The volatility of Russian fiscal policy is associated with a completely predictable fiscal response to the economic downturn caused by the global pandemic, when the monetary authorities are forced to focus their attention on the momentary realities of 


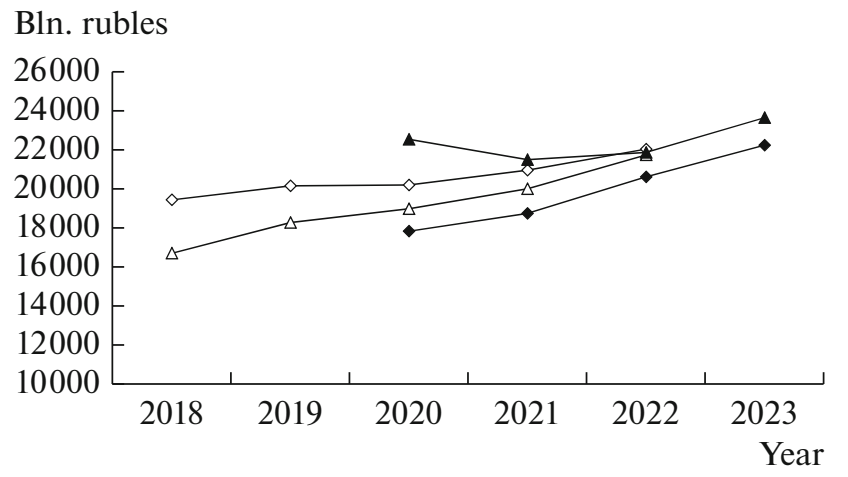

Fig. 1. Comparison of indicators of income and expenses in 2020-2022 and $2021-2023$ *:

$-\diamond-$ income 2020-2022; $-\triangle-$ expenses 2020-2022;

- - revenues 2021-2023: - $\mathbf{\Delta -}$ expenses 2021-2023.

*Source: website of the Ministry of Finance of Russia (www.minfin.ru).

budget balancing due to the need to quickly regroup the main items of expenditure in a mobilization economy.

The decisions taken in response to the "covid crisis" are likely to determine the vector of fiscal policy for many years to come. The pandemic accelerated the initiation of systemic changes not only in fiscal, but also in monetary policy (one can cite as an example some shocking new types of measures, such as "helicopter money," radical taxation measures) [2]. However, it should be understood that the current period of "large-scale nonstandard fiscal and monetary policy" [3], which has radically changed the approaches that have been practiced for decades, is urgent.

In the context of the need to resume economic growth, attention should be paid to the formation of a reliable theoretically grounded foundation for a longterm fiscal policy, which is impossible without changing the economic growth model [4]. At the same time, one should take into account the transformation of measures of the implemented financial policy that took place in different countries of the world [5].

Turning to the issue of the main macroeconomic indicators that underlie the formation of the Russian budget for 2021-2023, it should be noted that they are well known. At the same time, some figures presented in all budget documents, in particular, indicators of economic growth, need additional justification. In 2020 , Russia recorded a decline in GDP of 3.9\%, and in 2021 it is planned to increase by $3.3 \%$. Of course, due to the global pandemic in 2020, the actual macroeconomic indicators in Russia (as well as in other countries of the world) showed a serious deterioration due to a decrease in the production of national income. At the same time, a certain period of stagnation of the Russian economy in a certain way restrained the level of decline in key macroeconomic indicators [6]. However, the forecasted values presented raise certain doubts, especially since in subsequent years (planned period 2022-2023), the GDP growth rates should remain at approximately the same level (3-4\%).

Comparison of inflation targets with similar indicators of some EU countries shows that they are significantly higher in Russia. For example, in France inflation is forecasted in the range of $0.2-0.4 \%$, while in Russia the planned value of this indicator is approximately $3.8 \%$. At the same time, it is very likely that, at the end of 2021, its actual value may be at the level of approximately $4.2 \%$. Thus, according to the estimates of the Central Bank of Russia, at the end of February, the trend inflation reached $4.29 \%$ (the same indicator in January was $4.12 \%$ ). Meanwhile, in order to ensure macrofinancial stability, it is critically important to maintain a relatively low inflation rate [7].

The analysis of other characteristics of the federal budget for 2021 that are of most interest to us concerns their revenue and expenditure sides. First of all, it draws attention (which was expected) to a significant planned reduction in the volume of income (from 18.3 to $17.7 \%$ of GDP); at the end of the year, the actual value of this indicator may be even worse. In the next three years, the revenue side will remain at a little over $16 \%$ of GDP. So in 2021, revenues are projected at 18.765 billion rubles (lower the corresponding values for 2019). This means that there will be no recovery of the revenue base in the next three years. Figure 1 shows the changes in the planned volumes of revenues and expenditures of the federal budget in the last two budget cycles.

Actual and target (planned) values of budget indicators in the past (2020-2022) and current (20212023) budget cycles differ significantly. Thus, in 2020 the volume of lost income amounted to 2334.6 billion rubles, while expenses showed an increase of 3567.4 billion rubles. In the current budget cycle, a gradual economic recovery is expected, which will entail an increase in the revenue side of the Russian budget. As a percentage of GDP in 2021, the volume of revenues will demonstrate a decrease of $0.5 \%$ (from 16.7 in 2020 to $16.2 \%$ in 2021), however, it is planned that the strengthening of the national economy during the planning period will allow the transition to positive dynamics of this indicator in 2022-2023 (16.6 and $16.8 \%$, respectively).

At the same time, one should pay attention to the structure of the federal budget revenues of the Russian Federation and, first of all, to the volume of oil and gas revenues (Fig. 2).

Oil and gas revenues are projected to grow steadily over the current budget cycle. If in 2020 they accounted for $28.7 \%$ of federal budget revenues, then 


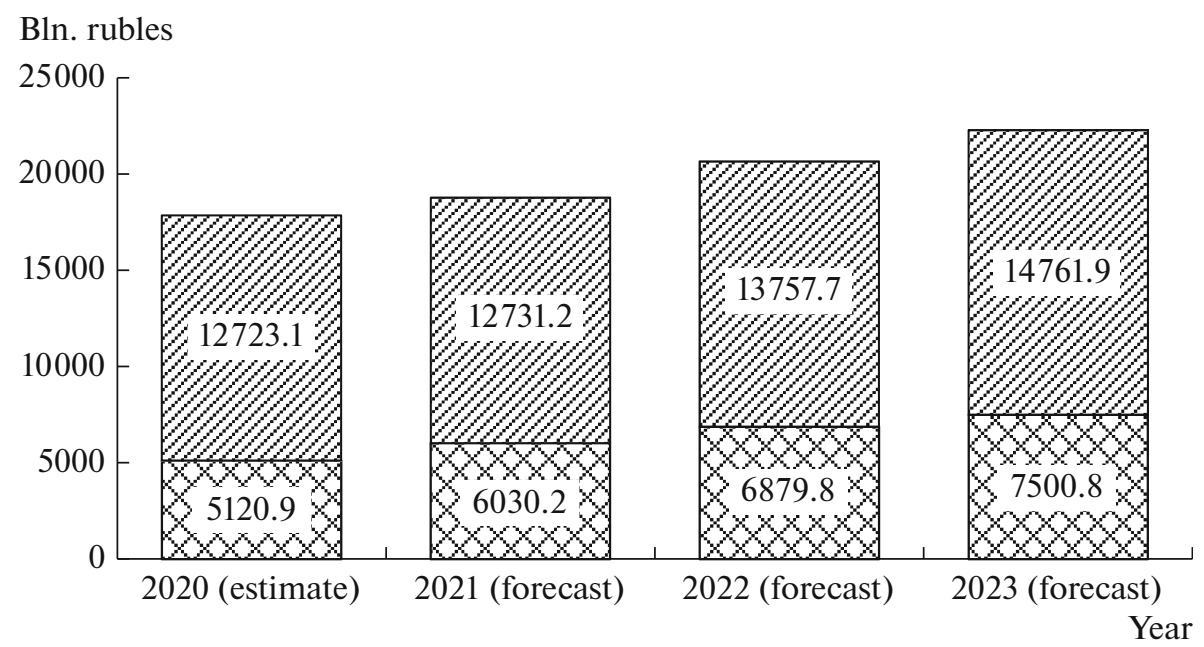

Fig. 2. The structure of the federal budget revenues of the Russian Federation in 2020-2023:

$\triangle$ the volume of oil and gas revenues; $\triangle$ volume of non-oil and gas revenues.

Source: Explanatory note to the draft federal law, On the Federal Budget for 2021 and for the Planning Period 2022 and 2023 (www.minfin.ru).

in 2021 this figure will be $32.1 \%$, and in 2023 it will reach $33.7 \%$. These figures look quite reliable and are consistent with the current forecasts of the Ministry of Economic Development of the Russian Federation in terms of growth in oil and gas production and exports. In this regard, interesting information related to export customs duties, which, in fact, are the export excise tax. Despite the fact that this practice does not fully comply with the principles of the WTO, it is actively used and (moreover) the volume of export customs duty on hydrocarbons is almost $22 \%$ of all oil and gas revenues in Russia.

When discussing tax revenues, it is advisable, first of all, to consider tax revenues related to regional issues: personal income tax and corporate income tax, which are the basis for the formation of the revenue base of regional budgets.

When analyzing forecasts for personal income tax, the planned significant increase in this indicator draws our attention. So, this year it is expected to receive 60000 million rubles, in 2022 an increase of more than 2.7 times (164096.4 million rubles), and in 2023 the volume of receipts will amount to 171487.3 million rubles (+7390.9 million rubles), i.e., over three years this indicator will increase by almost 2.9 times.

A more pessimistic picture is observed with respect to income tax: in the current budget cycle, a significant decrease in corporate income tax is expected when the production sharing agreement is fulfilled. In 2021, compared to 2020 , this indicator is projected to decrease by more than 2.5 times, and by 2023 it is expected to decrease by almost 3.5 times. When assessing the feasibility of these forecasts, one should take into account the long-term practice of the Ministry of Finance of Russia to overestimate (by about $10 \%$ ) the volume of revenues going to regional budgets, prompting the regions to take more active measures aimed at increasing the collection of relevant taxes.

In this regard, the initiative of the Russian government to activate the debt agenda of the regions, aimed at expanding the volume of debt financing of budget expenditures, is understandable. This reflects the intention of the central government, if possible, to restrain the growth of federal transfers to ensure the balance of regional budgets.

As for VAT, which is (along with oil and gas revenues) the cornerstone of the formation of the federal budget revenues, the opposite trend is observed in comparison with the profit tax, i.e., approximately the same (10\%) underestimation of forecasted receipts, which allows the financial department to obtain a kind of safety cushion in case of new fiscal shocks. A positive trend should be noted, reflecting an increase in the share of VAT in GDP. The current budget cycle will see an annual increase in VAT revenue. In 2021, the growth will amount to $0.2 \%$ of GDP (729611.8 million rubles), in $20220.3 \%$ (1429482.5 million rubles) and in 2023, $0.5 \%$ of GDP (2127871 million rubles).

Before proceeding to the consideration of budget expenditures, I would like to dwell on the annually published Open Budget Survey, on the basis of which the index of open budgets of different countries of the world is determined. In 2019, the index of the openness of the Russian budget was 74 (out of 100) and, according to this indicator, compared with the French 


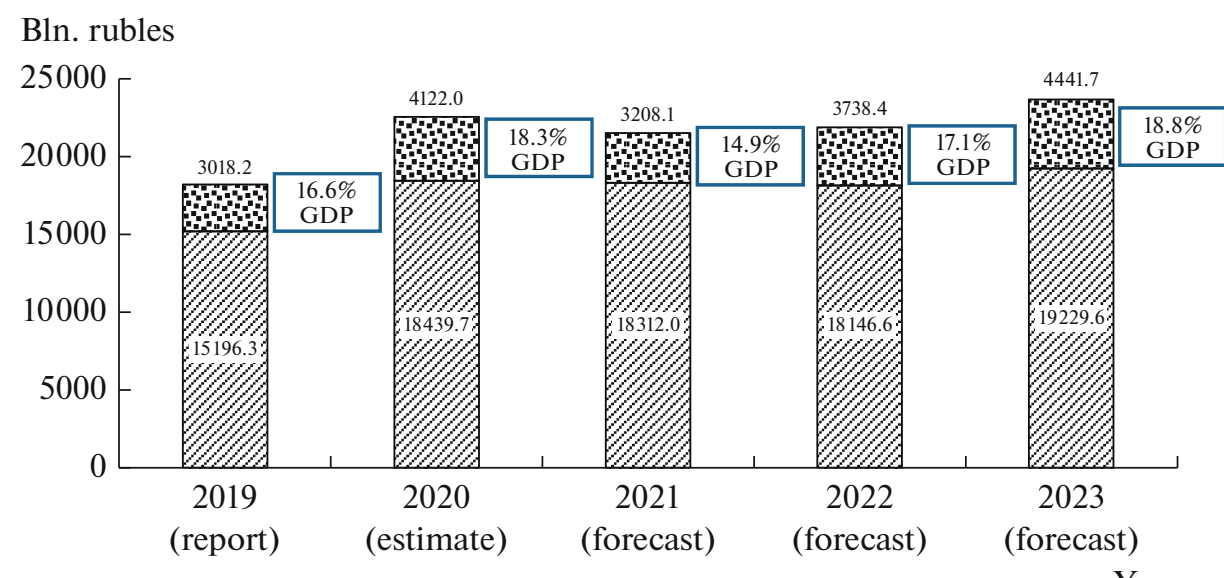

Fig. 3. Dynamics of open and closed expenses of the federal budget of Russia in 2019-2023:

$Q$ open costs; closed expenses.

Source: Explanatory note to the draft federal law, On the Federal Budget for 2021 and for the Planning Period of 2022 and 2023 (www.minfin.ru), conclusion of Gaidar Institute for Economic Policy on the draft Federal Law, On the Federal Budget for 2021 and for the Planning Period of 2022 and 2023 (https://www.iep.ru/ru/).

budget (in 2010, the level of transparency of the French budget was $87 / 100$, the rating of the openness of the French budget, according to experts, is declining rather quickly).

Despite the rather high value of the transparency index, there is a so-called closed part of expenditures in the Russian budget, the amount of which is showing steady growth. According to Gaidar Institute, if in 2012 their volume was $11.7 \%$ of the expenditure side, then in 2020 "secret" expenditures reached $18.8 \%$, which is almost a fifth of all budget expenditures (Fig. 3).

However, despite the increase in the share of closed expenditures, the index of the openness of the Russian budget has remained almost unchanged since 2012 (it is in the range of 72-74).

It is natural that Russia (like all countries in the world) reacted to the COVID-19 pandemic. According to the Accounts Chamber of the Russian Federation, $12.5 \%$ of total budget expenditures were spent on supporting the economy and providing assistance to the population ${ }^{1}$. However, the key challenge is to ensure that the funds are conducive to recovery and business development. The analysis showed that in 2021-2023, the volume of spending on infrastructure will increase by $1.7 \%$, which can provide the necessary development of the country's infrastructure complex. At the same time, the main growth in infrastructure spending is projected in 2022 (by 10\% in relation to 2021).

In general, the predicted trajectory of the dynamics of the main macroeconomic and budgetary indicators

\footnotetext{
${ }^{1}$ https://ach.gov.ru.
}

in the current budget cycle will be influenced by the new economic conditions that have developed over the past few years, under which the Russian economy is characterized by low rates of economic growth (compared to previous periods). The main reasons were both the persistence of structural imbalances and a significant drop in prices for goods that make up the bulk of the structure of Russian exports. Thus, the average annual price for Urals oil in 2020 amounted to $\$ 41.8$ per barrel, showing a decrease compared to the "dock" year of 2019, when the value of this indicator was $\$ 63.8$ per barrel $(-34.5 \%)$. The price in January 2021 rose to $\$ 54.4$ and almost reached the forecast values for 2021 of $\$ 56 / \mathrm{bbl}$ (Fig. 4).

In this regard, there is a possibility that in the period 2021-2023. budget risks will remain at a fairly high level due to the fact that the federal budget will not receive the planned revenues and the insufficient sources of financing the deficit, if it is necessary to increase certain items of budget expenditures.

Public debt: In search of the optimum (review of theoretical concepts). The next plot is related to the problem of balancing the budget against the background of growing deficit and (accordingly) public debt.

The growth of the budget deficit led to an increase in the volume of debt financing and, as a natural consequence, of the state debt. Issues related to the optimum of public debt should be considered in the context of its significance for the national economy of any country, since the volume, structure and growth rates of public debt directly affect the potential for sectoral and sectoral development. Reinhart and Rogoff [8], Sutherland and Hoelle [9], and Mertens [10] have achieved sig- 


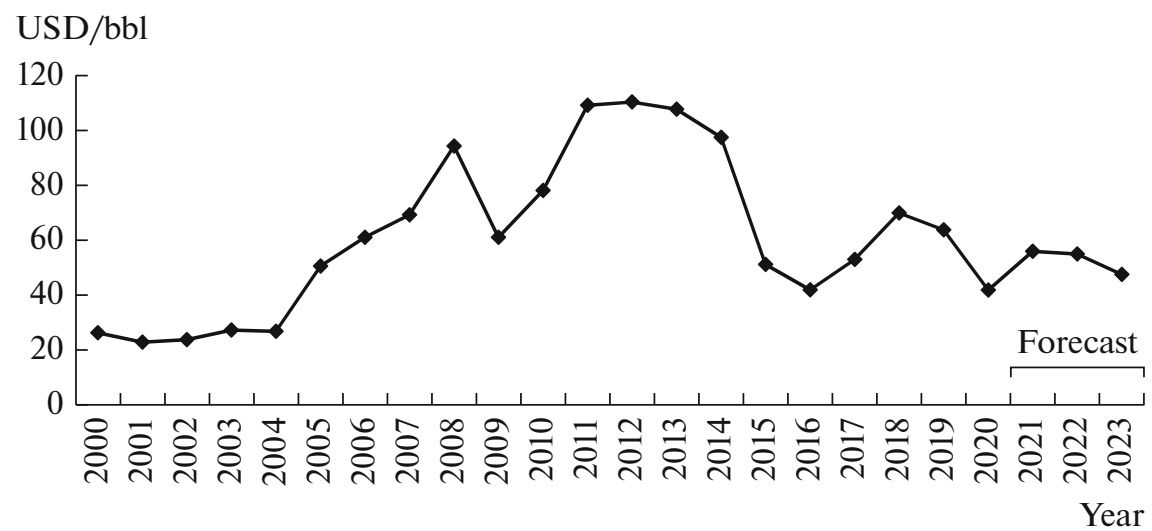

Fig. 4. Average price of Urals oil: dynamics by years 2000-2020 and forecast values in the current budget cycle (2021-2023) per barrel, USD.

Source: built on the basis of data from http://global-finances.ru.

nificant results regarding the assessment of the possibilities of using debt financing to stimulate GDP.

There is no consensus among economists about the interdependence of these indicators. In particular, based on materials from countries with different levels of economic development, it has been convincingly proven that "injections" of financial resources into the real sector in the short term can to some extent stimulate economic growth, but this effect appears only in the case of a slight increase in debt obligations. In the case of large-scale borrowing, negative dynamics of GDP indicators is observed [11, 12].

Of interest are the works [13-17], which analyze both the positive and negative consequences of the large-scale use of instruments of debt financing of the economy. At the same time, none of the above works contains convincing evidence regarding the optimum of public debt and its approximate values, after exceeding which the positive dynamics of growth are replaced by negative ones.

One cannot but agree with the opinion expressed in work [18] that the decision on what should be a safe level of public debt directly depends on the government, in particular, its ability to increase and maintain the primary surplus. At the same time, the author gives a number of arguments against the high level of public debt. Supporting (in general) the conclusions of the leading economist of the IMF, the authors believe that in the context of the implemented fiscal policy in the Russian context, a deeper discussion of the costs of debt is necessary than is currently the case.

At the same time, as the economic results of different countries of the world show, at present there is no empirical evidence and corresponding theoretical generalizations of the influence of the choice of the type of budget balance (deficit, surplus, "zero option") on the rate of economic growth. Moreover, in a postpandemic era, current projections suggest that the new economic "normal" may grow much more slowly than in past decades, so an increase in fiscal stimulus may not have any significant effect on economic growth. The main reason is that most emerging market countries do not have sufficient financial space to respond to macroeconomic shocks (including "pandemic" shocks). The authors of [19] consider the impact of fiscal expansion on output and government debt in the presence of hysteresis, a phenomenon that can manifest itself in a depressed economy when the use of fiscal incentives will have a zero effect on economic activity. Some Russian researchers adhere to a similar position (see, for example, [20]).

Expansionary fiscal policy may result in increased risks of significant capital outflows, falling commodity prices and, as a consequence, a depreciation of the national currency. The use of large-scale fully monetized fiscal stimulus without coordinated monetary policy measures can lead to uncontrolled inflation.

The analysis of the above studies devoted to the search for the optimal level of debt financing of the economy to ensure its progressive growth suggests that countries with emerging markets (including Russia) should be very careful to increase public debt, while maintaining its optimal structure based on the choice of the most effective instruments for financing the budget deficit.

Public debt and sources of financing the budget deficit. To stimulate and maintain stable economic growth, low volatility and predictability of key macroeconomic variables are critical. The fulfillment of this condition is necessary for the formation of a favorable regime for investment activity. At the same time, during the pandemic period, the use of debt instruments became the main trend in the fiscal policy of many countries, regardless of the level of develop- 


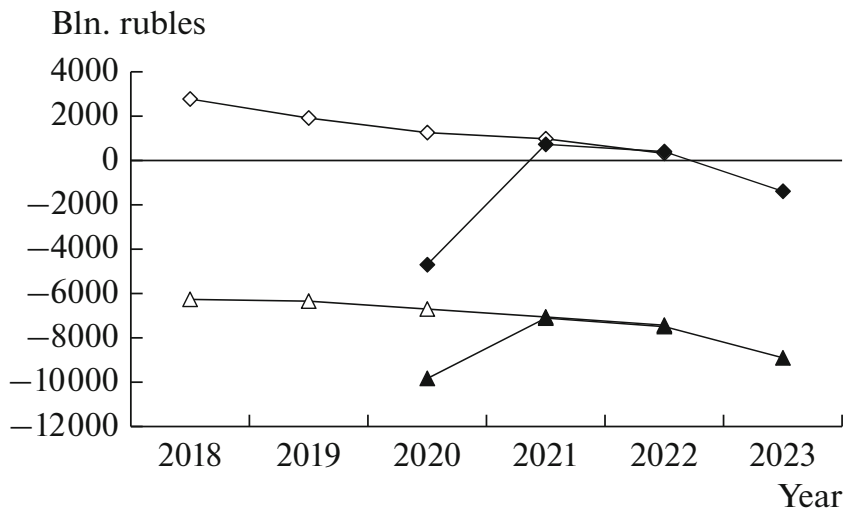

Fig. 5. Budget balance and indicators of nonoil and gas deficit in 2020-2022 and 2021-2023: $-\diamond-$ budgetary balance 2020-2022; - - - budgetary balance 2021-2023; $-\triangle-$ oil and gas deficit $2020-2022 ;-\Delta-$ oil and gas deficit 2021-2023.

Source: Explanatory note to the draft federal law, On the Federal Budget for 2020 and for the Planning Period of 2021 and 2022; Explanatory note to the draft federal law, On the Federal Budget for 2021 and for the Planning Period 2022 and 2023 (www.minfin.ru).

ment, since the lockdown regime required national governments to attract additional financial resources to the economy to compensate for the drop in household income and business structures. These actions led to a rapid increase in government spending and, especially, for a group of economically developed countries, in which the average growth rate of spending exceeded $12 \%$. A similar average for emerging market economies was about $4 \%$.

This practice has led to an increase in debt obligations unprecedented in world economic history. The realities of the "sanitary" war in just 10 months of 2020 led to an increase in the global volume of public debt to 89.6 trillion dollars, or $97.6 \%$ of GDP. Moreover, according to the IMF forecasts, by the end of this year this figure will increase by almost $2 \%$ (up to $99.5 \%$ of world GDP).

Obviously, this trend will continue in subsequent periods, since even with the implementation of the most optimistic scenario of the global economic recovery, there is no sufficient reason to expect the indicators of the absolute and relative level of government debt obligations to return to the values of 2019.

In the context of the above academic discussions focused on the role of debt financing in increasing demand and output in a recessionary economy and the efficiency of using debt to finance public investment, the trajectory of the Russian budget deficit within the current fiscal plans of the monetary authorities is of some concern (Fig. 5).

When considering the main sources of financing the federal budget deficit, the following points draw attention to themselves. First, the course continues to preserve the carbon model of the economy. Thus, the volume of financing the budget deficit looks very "modest," for example, through privatization (3.63.3 billion rubles) $)^{2}$. Second, the main source is government domestic borrowing (2937.6 billion rubles in 2021, 2099.0 in 2022 and 2387.8 in 2023). Thus, in the discussion between the Ministry of Economic Development and the Ministry of Finance on the sources of financing the deficit, the position of the latter prevailed, proposing to increase borrowing, while the Ministry of Economy considered it expedient to use the National Welfare Fund more actively.

Analysis of the main sources of financing the budget deficit for the period from 2021-2023, showed that in the period under review, there will be changes in the ratio of sources of financing; for example, it is planned that the deficit will be financed primarily by the growth of government debt. Thus, since 2020, there have been important transformational changes in the debt strategy of the Russian Federation, which marked the transition to market financing of the budget deficit.

In the course of implementing this debt strategy in 2020 , the total amount of government debt securities placed only in the domestic debt market exceeded 5.2 trillion rubles. This trend will be typical for both the current (2021-2023) and the next (2022-2024) budget cycle. At the same time, according to the authors, in the absence of sanctions on the Russian government debt, due to lower inflation expectations and (accordingly) credit premiums among market participants, by the middle of the third quarter of 2021, a decrease in volatility in the debt market can be predicted.

The gross volume of net attraction of funds through the placement of government securities denominated in the national currency will amount to 10039055.2 million rubles: in 2021 it is planned to raise funds in the amount of 3740340.3 million rubles, in 2022 3119993.7 million rubles, and in 2023, 3178721.2 million rubles. Plans for the placement of bonds of external bonded loans of the Russian Federation on the international and Russian capital markets in the current budget cycle imply an annual fundraising of up to $\$ 3000$ million, which will amount to slightly more than $5.8 \%$ (2021) and about $7 \%$ (2022 and 2023) ruble debt obligations.

In 2021-2023, further growth of the volume of the state debt of the Russian Federation is expected. At the end of 2021, its volume will amount to 23479.7 billion

\footnotetext{
${ }^{2}$ Explanatory note to the draft federal law, On the Federal Budget for 2020 and for the Planning Period of 2021 and 2022; Explanatory note to the draft federal law, On the Federal Budget for 2021 and for the Planning Period 2022 and 2023 (www.minfin.ru).
} 


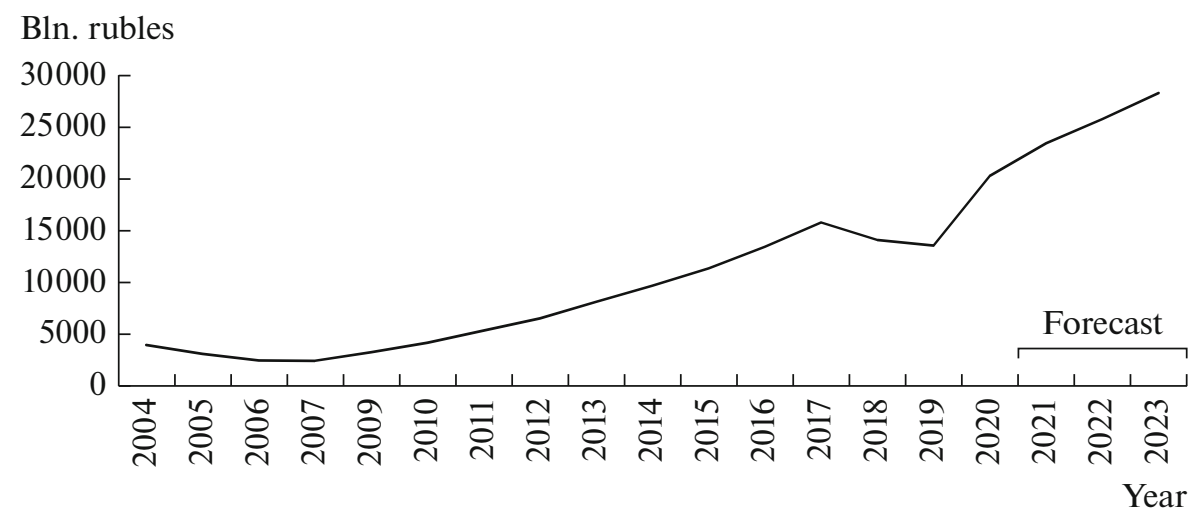

Fig. 6. Dynamics of the state debt of Russia in 2004-2023, billion rubles. Source: website of the Ministry of Finance of Russia (www.minfin.ru).

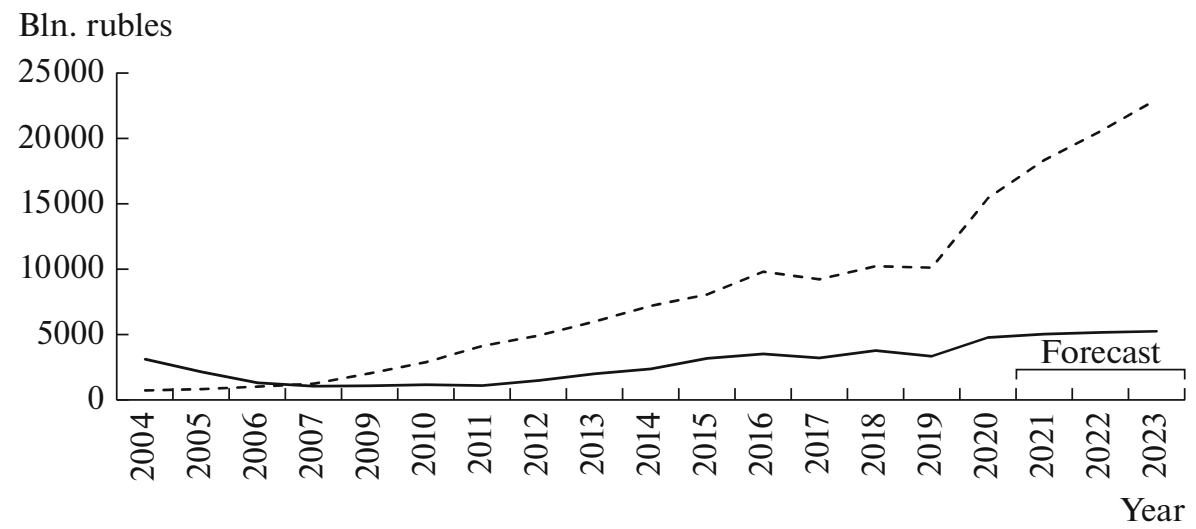

Fig. 7. Dynamics of changes in the volume of Russia's internal and external debt, 2004-2023: - - domestic debt; - external debt. Source: website of the Ministry of Finance of Russia (www.minfin.ru).

rubles, in 2022, 25810.4 billion rubles, and in 2023, 28336.1 billion rubles. The dynamics of changes in the state debt of Russia since 2004 are shown in Fig. 6.

When discussing the problem of public debt, one should, first of all, single out two figures concerning the increase in the level of debt obligations. At the end of 2019, the size of Russia's public debt amounted to $12.3 \%$ of GDP; by the end of 2023, this figure will increase to $21.3 \%$, i.e., in three years there will be a doubling of the national debt. For macroeconomic calculations, this is not such a significant figure, since in most countries of the world public debt is significantly higher, for example, in France it already amounts to $116 \%$ of GDP, that is, six times more than in Russia. However, what matters is not so much the volume of public debt as the ability to service it.

In addition to the increase in the size of the Russian state debt, there will be an annual increase in the cost of servicing it, the share of which will grow in revenues and expenditures of the federal budget. In the period

Table 1. Dynamics of the values of indicators of debt sustainability of the Russian Federation in 2011-2020, \%

\begin{tabular}{c|r|r|r|r|r|r|r|r|r|r}
\hline Indicator & 2011 & 2012 & \multicolumn{1}{|c|}{2013} & \multicolumn{1}{c|}{2014} & \multicolumn{1}{c}{2015} & 2016 & 2017 & 2018 & 2019 & 2020 \\
\hline I-1 & 8.9 & 9.1 & 10.3 & 13.0 & 13.2 & 12.9 & 12.6 & 13.5 & 12.3 & 19.0 \\
I-2 & 2.4 & 2.5 & 2.7 & 2.8 & 3.3 & 3.8 & 4.3 & 4.8 & 4.3 & 6.6 \\
I-3 & 2.3 & 2.5 & 2.8 & 2.9 & 3.8 & 4.7 & 4.7 & 4.1 & 4.0 & 6.2 \\
I-4 & 47.0 & 48.4 & 58.0 & 70.9 & 80.2 & 82.6 & 77.2 & 72.5 & 67.2 & 113.9 \\
\hline
\end{tabular}

Source. Calculated by authors from Russian Finance Ministry data (www.minfin.ru). 


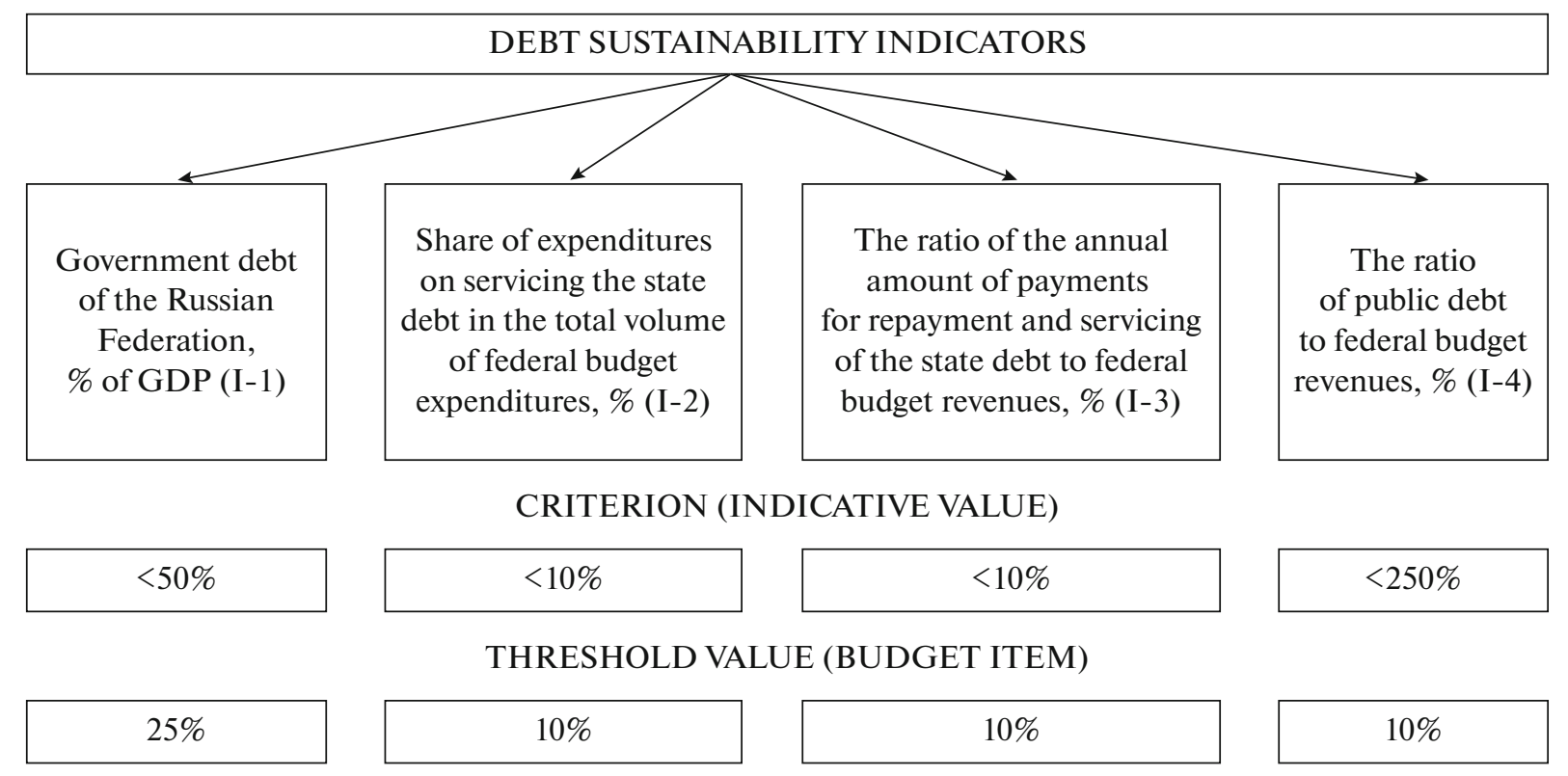

Fig. 8. Debt strength indicators with thresholds.

Source: suggested by authors.

from 2019 to 2023, the main growth in public debt occurs (and will continue to occur) due to an increase in domestic debt by almost 2.26 times (Fig. 7).

As you can see, in 2020, the growth of public domestic debt amounted to $52.3 \%$. In the current budget cycle (2021-2023), the planned growth rates will reach $18.7 \%$ in $2021,12 \%$ in 2022 and $11.8 \%$ in 2023 , while the growth rate of external debt will be in the range of $2-5 \%$ (in 2020 this figure was $42.3 \%$ ).

In the context of the projected further growth in the volume of public debt, it is advisable to assess the debt sustainability of the Russian Federation, during which, according to the authors, it is advisable to use the following set of indicators (Fig. 8).

The analysis showed that the stable growth of public debt does not have a significant effect on the values of the indicators of Russia's debt sustainability, they still remain within the threshold values (Table 1).

However, in connection with the projected further growth of debt obligations, one should pay attention to the fact that in the conditions of low rates of economic growth in the following periods, serious risks may arise.

Conclusions. In the face of limited financial resources and a slow economic recovery, the Russian authorities should take tough measures aimed at reducing the state budget deficit. This is because every percentage point of the budget deficit could potentially lead to an increase in the refinancing rate. Thus, it is necessary to urgently solve the problem of minimizing the dependence of internal macroeconomic conditions on the dynamics of external market conditions.

In the context of the projected growth of the budget deficit, the tasks associated with the need to increase the volume of debt financing of budget expenditures (including investment) are becoming more and more urgent. In a situation where it is impossible to use other ways to ensure high rates of economic growth, an increase in the Russian state debt is natural.

The new Russian debt strategy aimed at intensive growth of the debt burden has certain advantages, since the principle of debt financing presupposes a certain lag between the placement of government debt securities and their redemption, which gives obvious freedom for financial maneuver. The downside is the increased interest rate risk. This practice can set in motion an inflationary spiral and subsequently have a negative impact on real incomes of the population.

\section{REFERENCES}

1. L. Haffert, Permanent Budget Surplus as a Fiscal Regime. EUI Working Paper MWP 2015/10 (2015).

2. J. Aizenman and H. Ito, "Post COVID-19 exit strategies and emerging markets economic challenges," NBER Work. Pap., No. 27966 (2020).

3. C. M. Reinhart, "The coronavirus debt threat," Wall Street J., Mar. 26 (2020). https://www.wsj.com/articles/the-coronavirus-debt-threat-11585262515.

4. J. Cohen-Setton, E. Gornostay, and C. Ladreit, Aggregate of Budget Stimulus: Evidence from the Large Fiscal Expansions Database (Peterson Inst. Int. Econ., 2020), pp. 19-12. 
5. A. K. Moiseev, "Analysis of modern approaches to stimulating the development of the national economy with the help of financial instruments," Ekon. Strategii 21 (8), 24-29 (2019).

6. A. A. Shirov, "Opportunities and risks of post-crisis economic recovery," Nauchn. Tr. Vol'nogo Ekon. Ova. Ross., No. 3, 75-80 (2020). https://doi.org/10.38197/2072-2060-2020-223-3-75-80

7. D. B. Kuvalin, A. K. Moiseev, and A. A. Shirov, "The impact of price dynamics in Russia on monetary policy and economic development," Stud. Russ. Econ. Dev. 31, 533-540 (2020).

8. C. Reinhart and K. Rogoff, "From financial crash to debt crisis," Am. Econ. Rev. 101 (5), 1676-1706 (2011).

9. D. Sutherland and P. Hoelle, "Debt and macroeconomic stability: An overview of the literature and some empirics," OECD Econ. Dept. WP, No. 1006, 1-35 (2012).

10. K. Mertens, The Near Term Growth Impact of the Tax Cuts and Jobs Act (FRB Dallas, 2018).

11. C. Patillo, H. Poirson, and L. Ricci, "What are the channels through which external debt affects growth?," Int. Monetary Fund Work. Pap., No. 04/15, 1-33 (2004).

12. V. Ramey, "Can government purchases stimulate the economy?,” J. Econ. Liter. 49 (3), 673-685 (2011).
13. W. Moore and T. Chrystol, "A meta-analysis of the relationship between debt and growth," Munich Pers. RePEc Arch. Pap., No. 21474, 1-23 (2008).

14. M. Caner, T. Grennes, and F. Koehler-Geib, "Finding the tipping point - when sovereign debt turns bad," Policy Res. WP., No. 5391, 1-13 (2010).

15. J. Hanson, "The growth in government domestic debt changing burdens and risks," Policy Res. WP Ser., No. 4348, 1-38 (2007).

16. J. Cochrane, "Understanding policy in the Great Recession: Some unpleasant fiscal arithmetic," Eur. Econ. Rev. 55, 2-30 (2011).

17. N. Siti, D. Mohd, and J. Podivinsky, "Revisiting the role of external debt in economic growth of developing countries," J. Bus. Econ. Manage. 13 (5), 968-993 (2013).

18. O. Blanchard, "Public debt and low interest rates," Am. Econ. Rev. 109 (4), 1197-1229 (2019). https://doi.org/10.1257/aer.109.4.1197

19. B. DeLong and L. Summers, "Fiscal policy in a depressed economy,” Brookings Pap. Econ. Act. 43 (1), 233-297 (2012).

20. O. Dzh. Govtvan', “Monetary constraints on economic growth in Russia," Stud. Russ. Econ. Dev. 31, 647654 (2020). 